\title{
The CTLA4 variants may interact with the IL23R- and NOD2-conferred risk in development of Crohn's disease
}

\author{
Ondrej Hradsky*1, Petra Dusatkova1', Martin Lenicek², Jiri Bronsky', Jiri Nevoral', Libor Vitek2, Milan Lukas²,3, \\ Ivana Zeniskova ${ }^{4}$ and Ondrej Cinek ${ }^{1}$
}

\begin{abstract}
Background: The CTLA4 (cytotoxic T-lymphocyte antigen 4) gene is associated with several immunopathologic diseases and because of its important immuno-regulatory role it may be considered also a plausible candidate for a genetic association with inflammatory bowel diseases. Previously published studies found no association of CTLA4 with Crohn's disease itself, but some indicated an association with its subphenotypes. The aim of this study was to assess the association in the Czech population, using a set of markers shown to associate with other diseases.

Methods: Six polymorphisms within the CTLA4 region were investigated in 333 patients with Crohn's disease and 482 unrelated healthy controls, all Caucasians of Czech origin. The genotypes of the SNPs were determined using the TaqMan SNP genotyping assays. Haplotypes were reconstructed using an expectation-maximization algorithm, and their association with the condition was assessed using log-linear modeling. Then, potential interactions were tested between the CTLA4 variants and other genetic factors known to confer the disease susceptibility.

Results: No crude associations with Crohn's disease were found for the tested CTLA4 variants under the log-additive or dominant models. However, when stratified for the genetic risk conferred by the variants in the NOD2 (the p.Leu1007fsX1008, rs5743293) or the IL23R (p.R381Q, rs 11209026), a significant negative association emerged for the minor alleles of CTLA4 CT60 (rs3087243), JO31 (rs1 1571302), JO27-1 (rs11571297) polymorphisms. This negative association with CTLA4 was apparent only in the strata defined by presence minor alleles at the NOD2 $\mathrm{r} 55743293$ (here the CTLA4CT60 A coffered an OR =0.43, 95\%Cl 0.19 - 0.95 for the presence of CT60 A), or IL23R rs 11209026 (here the OR for presence of CT60 A was $0.23,95 \% \mathrm{Cl} 0.07$ - 0.71). We observed this effect also for the haplotype consisting of minor alleles of the three tightly linked CTLA4 markers. Furthermore, this haplotype was associated with the younger age at diagnosis (OR 1.52, 95\%Cl 1.09 - 2.11, $\mathrm{p}=0.014)$.

Conclusions: A protective effect of a CTLA4 haplotype was unmasked after stratification for the risk variants in the NOD2 and IL23R genes, and may point towards the biological relevance of the molecule in the pathogenesis of the disease.
\end{abstract}

\section{Background}

Crohn's disease (CD) belongs to inflammatory bowel diseases (IBD) that are characterized by chronic, relapsing and recurrent inflammation of intestinal mucosa. The disease is thought to result from the action of environmental factors in genetically susceptible individuals.

* Correspondence: ondrej.hradsky@lfmotol.cuni.cz

1 Department of Pediatrics, University Hospital Motol and Second Faculty of Medicine, Charles University in Prague, Prague, Czech Republic

Full list of author information is available at the end of the article
Three variants in the NOD2 [1,2], IBD5 locus [3] and one variant in the IL23R [4] and in the ATG16L1 [5] have been independently confirmed to be associated with $C D$, including associations found previously in the Czech population [6,7]. Recent studies, however, show that this list is far from being complete [5,8-12].

The CTLA4 gene may also be considered as a plausible candidate for a genetic association with IBD. Its product, the cytotoxic T-lymphocyte-associated protein 4 (CTLA4) is a T-cell suppressor which plays an essential 
role in the function of the $\mathrm{CD} 25(+) \mathrm{CD} 4(+)$ regulatory cells that control the process of intestinal inflammation $[13,14]$. The CTLA4 gene maps within the $2 \mathrm{q} 33$ region that has been found to carry suggestive linkage significance for IBD [15]. The CTLA4 gene is associated with other immunopathologic diseases (type 1 diabetes, Graves' disease, Addison's disease, celiac disease, systemic lupus erythematosus, rheumatoid arthritis, vitiligo) [16]. Among the studied single nucleotide polymorphisms (SNPs), the CT60 (rs3087243) shows the most prominent associations, being followed by other three SNPs: JO31 (rs11571302), JO30 (rs7565213) and JO27-1 (rs11571297) [16]. A recent publication has shown evidence for association of another SNP within the CTLA4 with type 1 diabetes, the rs1427676 [17]. Previously published papers about genetic association with $C D$ tested three variants in the CTLA4 gene: g.49A > G (rs231775), g. $-318 \mathrm{C}>\mathrm{T}$ (rs5742909) and the previously mentioned CT60, having found no association [18-21]. However, several works suggested that CTLA4 variants may influence the phenotype of CD $[18,19]$.

The aim of this study was to assess the association in the Czech population, using a set of markers previously shown to associate with other diseases.

\section{Methods Subjects}

In a case-control design, 333 Czech patients were compared to 482 unrelated healthy Czech controls representing a general population sample from the same geographical region. We tested 137 pediatric-onset patients (71 boys, 66 girls) who developed CD under or at the age of 18 years and were diagnosed according to the Porto criteria [22], and 196 adult onset patients (77 males, 119 females) diagnosed according to endoscopic, radiological, histological and clinical criteria. Phenotypic classification was done according to the Montreal Classification [23]. The demographic and clinical characteristics of the patients are listed in Table 1 and Table 2. The control group included 482 individuals: 295 children, 187 adult; 311 males, 171 females; median age 12 years, interquartile range 7-34 years. The study was approved by the
Ethics Committees of the authors' institutions, and a written informed consent was obtained from all participants or their guardians.

\section{Genotyping}

Genomic DNA was extracted from peripheral blood leukocytes with a routine salting out method, or from salivary samples using Oragene DNA Self-Collection Kit according the manufacturer's protocol (DNA Genotek Inc., Ottawa, Ontario, Canada). One SNP proximal to CTLA4 (rs736611), one from within the gene (g.49G > A, rs231775), and four SNPs located distally from the coding part of CTLA4 gene (rs3087243 also called CT60; rs11571302 called JO31; rs11571297 called JO27-1; and rs1427676) were selected based on available literature and genotyped using the TaqMan SNP genotyping assays (TaqMan SNP Genotyping Assay by Applied Biosystems, Foster City, CA, USA). The assays were run on an ABI 7300 machine (Applied Biosystems, Foster City, CA, USA) and evaluated according to manufacturer's instructions. To ensure consistency between runs, samples of known genotypes were repeated in every analysis. For testing interactions with other associated genes, we used genotypes generated in previously published studies on this sample set $[6,7]$.

\section{Statistical analysis}

The Hardy-Weinberg equilibrium was checked by comparing observed to expected genotype frequencies in the control subjects, and tested using exact tests. Associations of particular SNPs with CD were evaluated using odds ratios $(\mathrm{OR})$ with $95 \%$ confidence intervals $(\mathrm{CI})$. Haplotype analysis was performed by estimating the haplotype frequencies by the expectation-maximization algorithm implemented in the R-project package 'haplo.stats' version 1.3.1. Association of haplotypes with the conditions was tested using log-linear modeling. Then, a potential interaction between the CTLA4 variants and other genetic factors associated with the autoimmune conditions were tested. The statistical analysis was performed using the R-project package 'SNPassoc' version 1.5-2 [24].

Table 1: Demographic characteristics of patients and control subjects

\begin{tabular}{|c|c|c|c|c|}
\hline & \multicolumn{3}{|l|}{ CD patients } & \multirow[t]{2}{*}{ Control subjects $(n=482)$} \\
\hline & Total $(n=333)$ & Pediatric-onset CD $(n=137)$ & Adult-onset CD (n= 196) & \\
\hline Sex, M/F & $148 / 185$ & $71 / 66$ & $77 / 119$ & $311 / 171$ \\
\hline Age, median (interquartile range) & $21(14-30) 1$ & $14(12-16) 1$ & $28(23-35) 1$ & $12(7-34) 2$ \\
\hline
\end{tabular}


Table 2: Clinical characteristics of patients

\begin{tabular}{|c|c|c|c|}
\hline & $\begin{array}{l}\text { Total } \\
(n=333)\end{array}$ & $\begin{array}{l}\text { Pediatric-onset CD } \\
(n=137)\end{array}$ & $\begin{array}{l}\text { Adult-onset CD } \\
(n=196)\end{array}$ \\
\hline \multicolumn{4}{|l|}{ Age at diagnosis } \\
\hline A1 (<17 years) & 111 & 111 & 0 \\
\hline A2 (17 - 40 years) & 190 & 26 & 164 \\
\hline A3 (>40 years) & 32 & 0 & 32 \\
\hline \multicolumn{4}{|l|}{ Localization } \\
\hline L1 (terminal ileum) & $71(21 \%)$ & $23(17 \%)$ & $48(25 \%)$ \\
\hline L2 (colon) & $50(15 \%)$ & $13(9.5 \%)$ & $37(19 \%)$ \\
\hline L3 (ileocolon) & $208(63 \%)$ & $101(74 \%)$ & $107(55 \%)$ \\
\hline L 1-3 not determined & 4 & 0 & 4 \\
\hline L4 (Upper GI) ${ }^{1}$ & $56(17 \%)$ & $20(15 \%)$ & $36(18 \%)$ \\
\hline \multicolumn{4}{|l|}{ Disease behavior } \\
\hline B1 (nonstricturing/nonpenetraiting) & $138(42 \%)$ & 79 (59\%) & $59(30 \%)$ \\
\hline B2 (stricturing) & $129(39 \%)$ & $34(25 \%)$ & 95 (49\%) \\
\hline B3 (penetrating) & $62(18 \%)$ & $21(16 \%)$ & $41(21 \%)$ \\
\hline B 1-3 not determined & 4 & 3 & 1 \\
\hline B4 (perianal disease) & $109(33 \%)$ & $32(23 \%)$ & 77 (39\%) \\
\hline Extraintestinal manifestation ${ }^{2}$ & $53(16 \%)$ & $21(15 \%)$ & $32(17 \%)$ \\
\hline Need for surgery ${ }^{3}$ & $173(52 \%)$ & 41 (30\%) & $132(68 \%)$ \\
\hline
\end{tabular}

\section{Results}

\section{Crude associations}

The frequencies of the variants and respective $O R$ are listed in Table 3. No crude associations with CD were found for the tested SNPs under the log-additive or dominant models. The genotype distributions in control subjects conformed to Hardy-Weinberg equilibrium in all SNPs ( $p>0.20)$ except the rs1427676 ( $p=0.014$ in exact tests) which was therefore excluded from all further analyses.

As the part of chromosome under the CTLA4 gene is divided into the several blocks [16] we performed a haplotype analysis using the five SNPs; no crude association with CD was observed (data not shown).

\section{Interaction of the CTLA4 SNPs with variants in IL23R and NOD2}

We then tested possible interactions between variants in the CTLA4 and polymorphisms in other genes previously associated with CD: NOD2 gene p.Leu1007fsX1008 (c.3020insC), IL23R gene rs11209026 (c.1142G > A) [6,7], see Figure 1. This was done in dominant models using an
R-project package 'SNPassoc' version 1.5-2 [24]. Significant interactions were observed between the three CTLA4 variants (CT60, JO31, JO27-1) and NOD2 p.Leu1007fsX1008, and the same variants in the CTLA4 and IL23R rs11209026.

For a quantification of the CTLA4 association stratified by the above NOD2 and IL23R polymorphisms see Table 4 a Table 5: the minor alleles of the CT60, JO31 and JO271 within the CTLA4 modified the risk of Crohn's disease in the stratum of subjects carrying the frameshift insertion p.Leu1007fsX1008 in NOD2, while no perceivable effect of CTLA4 was found in the stratum of p.Leu1007fsX1008 wild-type homozygotes. Similarly, the three CTLA4 variants clearly, albeit moderately, decreased the risk of $C D$ in the stratum of subjects carrying minor alleles of rs11209026 within the IL23R (G/A and A/A), while no effect was observed in the IL23R wildtype homozygotes. The effect was observable also for the haplotype consisting of the three minor alleles of the variants in tight linkage disequilibrium, the CT60 "A", JO31 "T", JO27-1 "G" haplotype. 
Table 3: Distribution of genotypes of the studied CTLA4 polymorphisms' ${ }^{1}$

\begin{tabular}{|c|c|c|c|c|c|}
\hline \multirow{2}{*}{$\begin{array}{l}\text { Variants } \\
\text { rs736611 }\end{array}$} & \multicolumn{3}{|c|}{$\begin{array}{l}\text { Genotype frequency } \\
\text { cases } n=333, \text { controls } n=482\end{array}$} & \multirow{2}{*}{$\begin{array}{l}\text { Dominant model }^{2} \\
\text { Genotype } T / C+C / C\end{array}$} & \multirow{2}{*}{$\begin{array}{l}\text { Log-additive model }^{\mathbf{2}} \\
\text { Allele C }\end{array}$} \\
\hline & $\mathrm{T} / \mathrm{T}$ & $\mathrm{T} / \mathrm{C}$ & $\mathrm{C} / \mathrm{C}$ & & \\
\hline$C D$ & $37 \%$ & $48 \%$ & $15 \%$ & $63 \%$ & $39 \%$ \\
\hline Controls & $34 \%$ & $48 \%$ & $18 \%$ & $66 \%$ & $42 \%$ \\
\hline OR $(95 \% \mathrm{Cl})$ & & & & $0.89(0.67-1.19)$ & $0.86(0.70-1.05)$ \\
\hline g.49A > G (rs231775) & $\mathrm{A} / \mathrm{A}$ & $\mathrm{A} / \mathrm{G}$ & $\mathrm{G} / \mathrm{G}$ & Genotype A/G + G/G & Allele G \\
\hline$C D$ & $41 \%$ & $46 \%$ & $13 \%$ & $59 \%$ & $36 \%$ \\
\hline Controls & $40 \%$ & $44 \%$ & $16 \%$ & $61 \%$ & $38 \%$ \\
\hline OR $(95 \% \mathrm{Cl})$ & & & & $0.85(0.63-1.14)$ & $0.89(0.72-1.09)$ \\
\hline CT60 (rs3087243) & $\mathrm{G} / \mathrm{G}$ & $\mathrm{G} / \mathrm{A}$ & $\mathrm{A} / \mathrm{A}$ & Genotype G/A + A/A & Allele A \\
\hline$C D$ & $33 \%$ & $48 \%$ & $19 \%$ & $68 \%$ & $43 \%$ \\
\hline Controls & $35 \%$ & $48 \%$ & $17 \%$ & $65 \%$ & $41 \%$ \\
\hline OR $(95 \% \mathrm{Cl})$ & & & & $1.11(0.82-1.50)$ & $1.10(0.90-1.35)$ \\
\hline J031 (rs11571302) & $\mathrm{G} / \mathrm{G}$ & $\mathrm{G} / \mathrm{T}$ & $\mathrm{T} / \mathrm{T}$ & Genotype G/T + T/T & Allele T \\
\hline$C D$ & $29 \%$ & $50 \%$ & $21 \%$ & $71 \%$ & $46 \%$ \\
\hline Controls & $31 \%$ & $49 \%$ & $20 \%$ & $69 \%$ & $44 \%$ \\
\hline OR $(95 \% \mathrm{Cl})$ & & & & $1.12(0.82-1.53)$ & $1.09(0.89-1.34)$ \\
\hline JO27-1 (rs11571297) & $\mathrm{A} / \mathrm{A}$ & $\mathrm{A} / \mathrm{G}$ & $\mathrm{G} / \mathrm{G}$ & Genotype A/G + G/G & Allele G \\
\hline$C D$ & $29 \%$ & $49 \%$ & $22 \%$ & $72 \%$ & $47 \%$ \\
\hline Controls & $30 \%$ & $50 \%$ & $20 \%$ & $70 \%$ & $45 \%$ \\
\hline OR $(95 \% \mathrm{Cl})$ & & & & $1.12(0.82-1.53)$ & $1.11(0.91-1.36)$ \\
\hline
\end{tabular}

1: the rs1427676 polymorphism was excluded from the analyses as its distribution among healthy population did not conform to Hardy Weinberg equilibrium.

2: Adjusted by gender

\section{Genotype - phenotype analysis}

Using a case-only design, we tested whether the phenotypic characteristics of the patients are dependent on carriage status of the minor alleles at CTLA4 variants.

Table 6 shows logistic regression with the outcomes of clinical characteristics and the three CTLA4 variants and the haplotype as the predictors. The pediatric-onset patients differed to the adult-onset patients in their frequencies of the minor allele at the CT60 (74\% versus 63\%, $\mathrm{p}=0.03)$. The CT60, JO31 and JO27-1 SNPs, as well as their "ATG" haplotype retained their associations with the age at diagnosis after adjustment to the effect of the NOD2 variant (p.Leu1007fsX1008). No difference between pediatric and adult-onset group was found for the other two variants in the CTLA4 gene, data not shown.
The CTLA4 variants were weakly associated with the ileal-only (L1) and ileocolonic involvement (L3) in a dominant manner, while no association was observed with any of the remaining clinical characteristics: localization in the upper gastrointestinal tract, the stricturing or penetrating behavior of the disease, perianal disease, extraintestinal manifestation, or the need for abdominal surgery (data not shown).

\section{Discussion}

The immunologic importance of the CTLA4 gene is in striking contrast to the lack of knowledge on the functional relevance of its numerous polymorphisms. Consequently, many groups have investigated various polymorphisms located within various regions of the gene. The first published study on CTLA4 variants in CD investigated the g.49A > G (rs231775) and g.-318C > T 


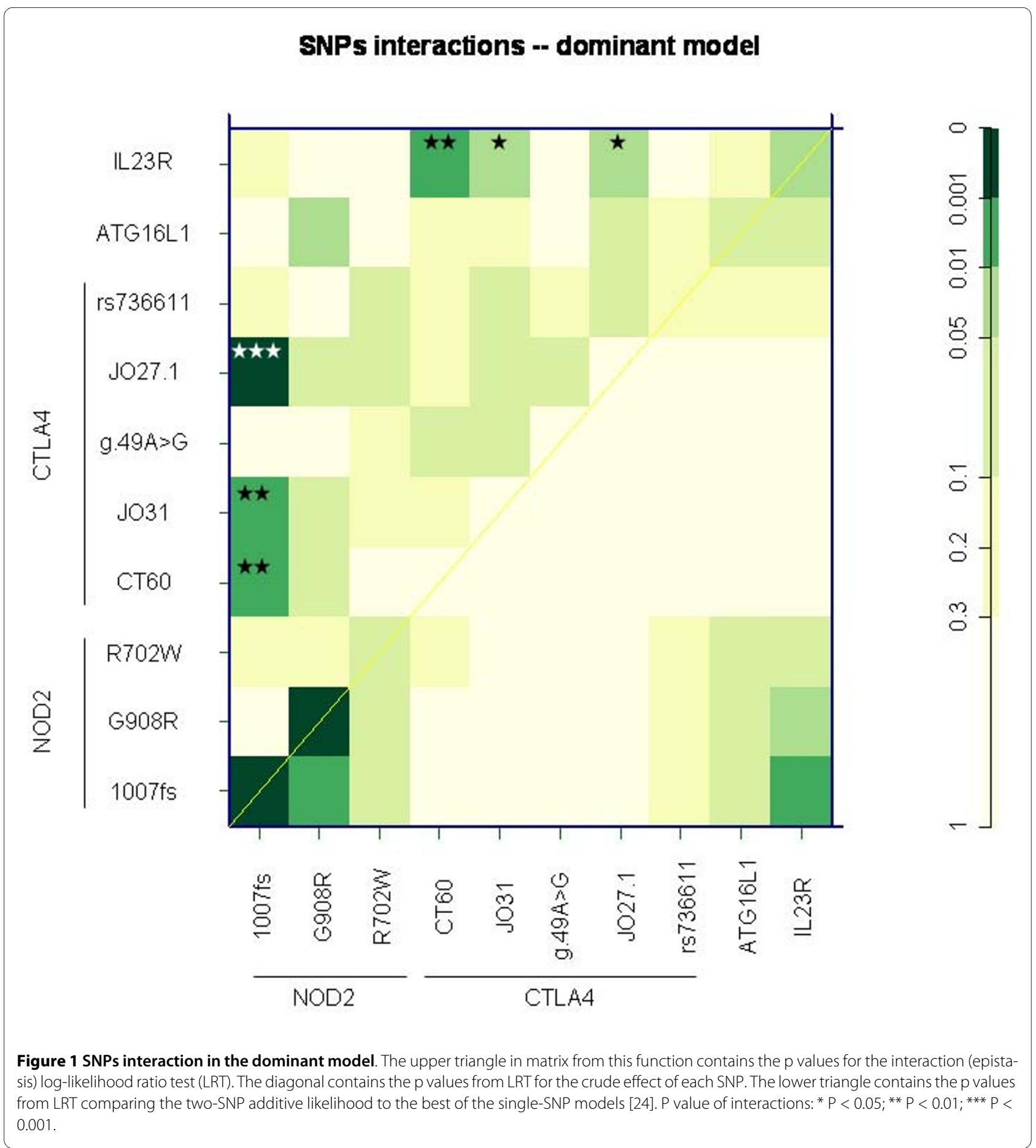

(rs5742909) in the Dutch and the Chinese populations, finding only an association with the age of onset [18]. Similarly, in a Hungarian work, no association of g.49A > $\mathrm{G}$ with $\mathrm{CD}$ was detected [21]. Since the work by Ueda et al [16] had been published on dissecting the association of CTLA4 with immunopathological diseases, further investigators focused on the CT60 polymorphism. This variant was studied in the Japanese [19] and the Spanish
[20] populations, however no crude association with $C D$ was detected. The G/G genotype of g.49A > G was associated with penetrating form of $C D$ in the Japanese dataset [19]. No association within 2q33 chromosomal region has been found by genome-wide studies [4,5,8-12].

Thus, compelling evidence has been gathered against simple association of the disease itself with the polymorphisms of CTLA4. In line with these findings, we 
Table 4: Stratified analysis of the effect conferred by the CTLA4 CT60, JO31 and J027-1 variants

\begin{tabular}{|c|c|c|c|c|}
\hline $\begin{array}{l}\text { NOD2 stratum } \\
\text { defined using the } \\
\text { Leu1007fsX1008 } \\
\text { polymorphism 1) }\end{array}$ & $\begin{array}{l}\text { CT60 (rs3087243), } \\
\text { A carriage rate } \\
\text { (genotypes A/G, A/A) }\end{array}$ & $\begin{array}{l}\text { J031 (rs11571302), } \\
\text { T carriage rate } \\
\text { (genotypes G/T, T/T) }\end{array}$ & $\begin{array}{l}\text { JO27-1 (rs11571297), } \\
\text { G carriage rate } \\
\text { (genotypes A/G, G/G) }\end{array}$ & Haplotype "ATG" 4 \\
\hline \multicolumn{5}{|l|}{ NOD2 "+" } \\
\hline cases, $n=108$ & $67(62 \%)$ & 69 (64\%) & 70 (65\%) & \\
\hline controls, $n=48$ & $38(79 \%)$ & $40(83 \%)$ & $42(88 \%)$ & \\
\hline OR $(95 \% \mathrm{Cl}){ }^{2)}$ & $\mathbf{0 . 4 3}(0.19-0.95)$ & $0.35(0.15-0.83)$ & $0.26(0.1-0.68)$ & $0.62(0.37-1.05)$ \\
\hline \multicolumn{5}{|l|}{ NOD2 "wt/wt" } \\
\hline cases, $n=224$ & $157(70 \%)$ & $166(74 \%)$ & $168(75 \%)$ & \\
\hline controls, $n=434$ & $277(64 \%)$ & $292(67 \%)$ & $294(68 \%)$ & \\
\hline $\mathrm{OR}(95 \% \mathrm{Cl}){ }^{2)}$ & $1.33(0.94-1.88)$ & $1.37(0.96-1.96)$ & $1.42(0.99-2.03)$ & $1.21(0.96 .-1.53)$ \\
\hline $\begin{array}{l}\text { Heterogeneity between } \\
\text { NOD2-defined strata } 3 \text { ) }\end{array}$ & $p=0.011$ & $p=0.0042$ & $p=0.0011$ & $p=0.043$ \\
\hline \multicolumn{5}{|c|}{$\begin{array}{l}\text { Strata of the risk conferred by the p.Leu1007fsX1008 polymorphism of the NOD2 gene: the effect of CTLA4 is apparent in the stratum with an } \\
\text { increased NOD2-associated risk } \\
\text { 1) NOD2 "+": homozygous or heterozygous for the minor allele at the p.Leu1007fsX1008 polymorphism; NOD2 "wt/wt": wild-type homozygote at } \\
\text { the p.Leu1007fsX } 1008 \text { polymorphism. The NOD2 "+" category is associated with an increased risk of OR=4.36, } 95 \% \mathrm{Cl} 2.95-6.49 \text { as compared to } \\
\text { "wt/wt" category. } \\
\text { 2) OR for the effect of the polymorphism in the specific stratum (NOD2"+" and NOD2"wt/wt"), adjusted for the effect of the IL23R p.381Gln variant } \\
\text { and p.Gly908Arg, p.Arg702Trp in the NOD2 gene. Results significant at } \mathrm{p}<0.05 \text { are in bold. } \\
\text { 3) Heterogeneity in the effect conferred by the CTLA4 polymorphisms was assessed between NOD2-defined strata using the Mantel-Haenszel } \\
\text { test of homogeneity. } \\
\text { 4) The implemented expectation-maximization algorithm did not allow individual imputation and counting of haplotypes. }\end{array}$} \\
\hline
\end{tabular}

observed no crude association unless further genetic factors were taken into account. However, when CTLA4 was considered as a modifier of the effects conferred by the NOD2 and IL23R genes, possible interactions substantiated. Interactions in multifactorial immunopathological diseases are not infrequent: in $C D$, the interactions with the NOD2 gene were detected in the IBD5 locus [25], IBD6 locus [15], TNFA [26], DLG5 [27], ATG16L1[28], IL23R [29], TLR4 [30] and in CD14 [30]. The interaction was also found between IBD5 locus and IL23R [31] and between Toll-like receptor-9 polymorphisms and variants in NOD2 and IL23R [32].

The interactions we found for the CT60, JO31, JO27-1 variants of CTLA4 (or their haplotype) with the p.Leu $1007 \mathrm{fs} X 1008$ variant of NOD2 may imply that the effect of the strongest risk variant within the NOD2 (p.Leu1007fsX1008) can be expressed better on the background of the common CTLA4 haplotype. This is suggestive of a complex pattern of gene-gene interaction that may merit pursuing further functional studies. Similarly, the risk haplotype of CTLA4 also interacts with the $I L 23 R$ protective variants. This rather weak interaction can be also due to the relatively limited size of the dataset.

In addition to the modifying effect on the risk of the disease itself, we observed an association with the age at onset and the disease subphenotypes. Indeed, the impact of genetic factors in early-onset patients with CD seems to be stronger than in adult-onset patients (reviewed by de Ridder L et al. [33]). In our dataset, the age at diagnosis was associated with CT60, JO31 and JO27-1. Influence of CTLA4 variants on the age at diagnosis has been previously described by Xia et al, although with a different SNP (g.-318C > T) [18]. Moreover, their patients were divided into groups where 40 years of age was the cut off, not 18 years as in our study.

The CTLA4 was associated with the ileal and ileocolonic involvement in our case set: up to our knowledge, this is the first time when localization of CD is influenced by any variant within CTLA4. It should be however noted that these associations are weak, merit further investigation in other populations, and their clinical relevance can be only hardly envisaged. The ileal form of disease has been shown more common in adult-onset patients and more common in patients carrying minor variants of the NOD2 gene. A possible explanation of the association of CTLA4 with localization of disease might be found in the interaction between CTLA4 and NOD2 gene.

Similarly to Machida et al [19] we also tested whether the g.49A > G variant influences the occurrence of penetrating disease, but we were not able to confirm this association. However, the genetic background between Japanese and Czech populations differs markedly. 
Table 5: Stratified analysis of the effect conferred by the CTLA4 CT60, J031 and J027-1 variants

\begin{tabular}{|c|c|c|c|c|}
\hline $\begin{array}{l}\text { IL23R stratum } \\
\text { defined using the } \\
\text { p.Arg381GIn } \\
\text { polymorphism 1) }\end{array}$ & $\begin{array}{l}\text { CT60 (rs3087243), } \\
\text { A carriage rate } \\
\text { (genotypes A/G, A/A) }\end{array}$ & $\begin{array}{l}\text { JO31 (rs11571302), } \\
\text { T carriage rate } \\
\text { (genotypes G/T, T/T) }\end{array}$ & $\begin{array}{l}\text { J027-1 (rs11571297), } \\
\text { G carriage rate } \\
\text { (genotypes A/G, G/G) }\end{array}$ & Haplotype "ATG" 4 \\
\hline \multicolumn{5}{|l|}{ IL23R "-" } \\
\hline cases, $\mathrm{n}=21$ & $10(48 \%)$ & $10(48 \%)$ & $10(48 \%)$ & \\
\hline controls, $\mathrm{n}=50$ & $42(84 \%)$ & $40(80 \%)$ & 40 (80\%) & \\
\hline OR $(95 \% \mathrm{Cl})^{2)}$ & $0.23(0.07-0.71)$ & $0.26(0.08-0.85)$ & $0.24(0.07-0.79)$ & $\mathbf{0 . 3 0}(0.11-0.81)$ \\
\hline \multicolumn{5}{|l|}{ IL23R "wt/wt" } \\
\hline cases, $\mathrm{n}=312$ & $214(69 \%)$ & $224(72 \%)$ & $227(73 \%)$ & \\
\hline controls, $n=432$ & $276(64 \%)$ & $292(68 \%)$ & $296(69 \%)$ & \\
\hline OR (95\%Cl) 2) & $1.26(0.91-1.74)$ & $1.22(0.87-1.71)$ & $1.21(0.86-1.69)$ & $1.20(0.96-1.51)$ \\
\hline $\begin{array}{l}\text { Heterogeneity } \\
\text { between } \\
\text { IL23R-defined strata 3) }\end{array}$ & $p=0.0061$ & $p=0.011$ & $p=0.011$ & $p=0.030$ \\
\hline
\end{tabular}

Strata of the risk conferred by the p.Arg381GIn polymorphism of the IL23R gene: the effect of CTLA4 is apparent in the stratum with an IL23Rassociated protective effect

1) IL23R "-": homozygote or heterozygote for the IL23R p.381GIn allele; IL23R "wt/wt": wild-type homozygote at the p.Arg381Gln polymorphism. The IL23R "-" category is associated with a decreased risk of $\mathrm{OR}=0.58,95 \% \mathrm{Cl} 0.32-1.00$ as compared to the "wt/wt" category. 2) OR for the effect of the polymorphism in the specific stratum (IL23R "-" or IL23R "wt/wt"), adjusted for the effect of p.Leu1007fsX1008, p.Gly908Arg, and p.Arg702Trp in the NOD2 gene. Results significant at $\mathrm{p}<0.05$ are in bold.

3) heterogeneity in the effect conferred by the CTLA4 polymorphisms was assessed between IL23R-defined strata using the Mantel-Haenszel test of homogeneity.

4) The implemented expectation-maximization algorithm did not allow individual imputation and counting of haplotypes.

\section{Conclusions}

We present a study of genetic association of polymorphisms within the CTLA4 gene with CD and its subphenotypes, using a representative set of markers previously reported from other studies. We observed interactions of the CTLA4 haplotype with variants in NOD2 and IL23R genes, and detected an effect of three variants of the CTLA4 on the age at diagnosis and localization of the disease.

Table 6: Genotype-phenotype analysis ${ }^{1}$

\begin{tabular}{|c|c|c|c|c|}
\hline Outcome & $\begin{array}{l}\text { CT60 (rs3087243) } \\
\text { allele A }\end{array}$ & $\begin{array}{l}\text { J031 (rs11571302) } \\
\text { allele T }\end{array}$ & $\begin{array}{l}\text { J027-1 (rs11571297) } \\
\text { allele G }\end{array}$ & "ATG" haplotype \\
\hline Ileal involvement (L1) & $\begin{array}{l}0.41 \\
(0.24-0.70) \\
\mathbf{p}=\mathbf{0 . 0 0 1 2}\end{array}$ & $\begin{array}{l}0.45 \\
(0.26-0.78) \\
\mathbf{p}=\mathbf{0 . 0 0 5 2}\end{array}$ & $\begin{array}{l}0.43 \\
(0.24-0.74) \\
\mathbf{p}=\mathbf{0 . 0 0 2 7}\end{array}$ & $\begin{array}{l}0.70 \\
(0.47-1.05) \\
\mathbf{p}=\mathbf{0 . 0 8 1}\end{array}$ \\
\hline Ileocolonic involvement (L3) ${ }^{3}$ & $\begin{array}{l}1.97 \\
(1.21-3.19) \\
\mathbf{p}=\mathbf{0 . 0 0 5 9}\end{array}$ & $\begin{array}{l}1.91 \\
(1.16-3.13) \\
\mathbf{p}=\mathbf{0 . 0 1 0}\end{array}$ & $\begin{array}{l}1.94 \\
(1.18-3.20) \\
\mathbf{p}=\mathbf{0 . 0 0 9 0}\end{array}$ & $\begin{array}{l}1.54 \\
(1.09-2.17) \\
\mathbf{p}=\mathbf{0 . 0 1 4}\end{array}$ \\
\hline
\end{tabular}

1: OR with their $95 \% \mathrm{Cl}$ come from logistic regression analysis using dominant models, with the clinical phenotype as an outcome and CTLA4 CT60, JO31, JO27-1 minor variants and ATG haplotype as predictors; the models are adjusted for the p.Leu $1007 \mathrm{fsX} 1008$ variant in the NOD2 gene. 2: Patients having been diagnosed before or at the age of 18 years.

3: Further, we tested interaction between NOD2 p.Leu1007fsX1008 variant and the CTLA4 ATG haplotype on development of L3. Comparing to wild haplotype on the background of the ATG haplotype the association of p.Leu1007fsX1008 NOD2 high risk variant was significantly weaker. P-value of the interaction between ATG haplotype and NOD2 p.Leu1007fsX1008 in the development of L3 was estimated 0.026. 


\section{Competing interests}

The authors declare that they have no competing interests.

\section{Authors' contributions}

$\mathrm{OH}, \mathrm{PD}$ and MLe performed the experiments; JB, JN, LV, MLu coordinated and performed the collection of the samples and were also involved in editing the manuscript; $\mathrm{OC}$ and $\mathrm{OH}$ designed the study and wrote the manuscript. All authors read and approved the final manuscript.

\section{Acknowledgements}

This study was supported by grants from the Czech Ministry of Health (MZOFNM2005), the University Hospital Motol and IGA - NR/9219-3/2007. Drs V. Valtrova, P.Szitanyi, R. Petro, M. Bortlik and V. Starzykova are gratefully acknowledged for providing us with samples and clinical data from their patients

\section{Author Details}

'Department of Pediatrics, University Hospital Motol and Second Faculty of Medicine, Charles University in Praque, Prague, Czech Republic, 2Institute of Clinical Biochemistry and Laboratory Diagnostics, First Faculty of Medicine, Charles University in Prague, Prague, Czech Republic, 3|BD Clinical and Research Center, ISCARE I.V.F. Lighthouse, Prague, Czech Republic and ${ }^{4}$ Keské BudEjovice Hospital a.s., Жeské BudEjovice, Czech Republic

Received: 9 November 2009 Accepted: 10 June 2010 Published: 10 June 2010

\section{References}

1. Hugot JP, Chamaillard M, Zouali H, Lesage S, Cézard JP, Belaiche J, Almer S, Tysk C, O'Morain CA, Gassull M, et al:: Association of NOD2 leucine-rich repeat variants with susceptibility to Crohn's disease. Nature 2001, 411(6837):599-603.

2. Ogura Y, Bonen DK, Inohara N, Nicolae DL, Chen FF, Ramos R, Britton H, Moran T, Karaliuskas R, Duerr RH, et al: A frameshift mutation in NOD2 associated with susceptibility to Crohn's disease. Nature 2001 411(6837):603-606

3. Rioux JD, Daly MJ, Silverberg MS, Lindblad K, Steinhart H, Cohen Z, Delmonte T, Kocher K, Miller K, Guschwan S, et al: Genetic variation in the 5 q31 cytokine gene cluster confers susceptibility to Crohn disease. Nat Genet 2001, 29(2):223-228

4. Duerr RH, Taylor KD, Brant SR, Rioux JD, Silverberg MS, Daly MJ, Steinhart AH, Abraham C, Regueiro M, Griffiths A, et al:: A genome-wide association study identifies IL23R as an inflammatory bowel disease gene. Science 2006, 314(5804):1461-1463.

5. Rioux JD, Xavier RJ, Taylor KD, Silverberg MS, Goyette P, Huett A, Green T, Kuballa P, Barmada MM, Datta LW, et al: Genome-wide association study identifies new susceptibility loci for Crohn disease and implicates autophagy in disease pathogenesis. Nat Genet 2007, 39(5):596-604.

6. Hradsky O, Lenicek M, Dusatkova P, Bronsky J, Nevoral J, Valtrova V, Kotalova R, Szitanyi P, Petro R, Starzykova V, et al: Variants of CARD15, TNFA and PTPN22 and susceptibility to Crohn's disease in the Czech population: high frequency of the CARD15 1007fs. Tissue Antigens 2008, 71(6):538-547.

7. Dusatkova P, Hradsky O, Lenicek M, Bronsky J, Nevoral J, Kotalova R, Bajerova K, Vitek L, Lukas M, Cinek O: Association of IL23R p.381GIn and ATG16L1 p.197Ala With Crohn Disease in the Czech Population. J Pediatr Gastroenterol Nutr 2009, 49(4):405-10.

8. The Wellcome Trust Case Control Consortium: Genome-wide association study of 14,000 cases of seven common diseases and 3,000 shared controls. Nature 2007, 447(7145):661-678

9 Barrett JC, Hansoul S, Nicolae DL, Cho JH, Duerr RH, Rioux JD, Brant SR, Silverberg MS, Taylor KD, Barmada MM, et al:: Genome-wide association defines more than 30 distinct susceptibility loci for Crohn's disease. Nat Genet 2008, 40(8):955-962

10. Tremelling M, Parkes M: Genome-wide association scans identify multiple confirmed susceptibility loci for Crohn's disease: lessons for study design. Inflamm Bowel Dis 2007, 13(12):1554-1560,

11. Parkes M, Barrett JC, Prescott NJ, Tremelling M, Anderson CA, Fisher SA Roberts RG, Nimmo ER, Cummings FR, Soars D, et al:: Sequence variants in the autophagy gene IRGM and multiple other replicating loci contribute to Crohn's disease susceptibility. Nat Genet 2007 39(7):830-832

12. Libioulle C, Louis E, Hansoul S, Sandor C, Farnir F, Franchimont D, Vermeire S, Dewit O, de Vos M, Dixon A, et al:: Novel Crohn disease locus identified by genome-wide association maps to a gene desert on $5 \mathrm{p} 13.1$ and modulates expression of PTGER4. PLoS Genet 2007, 3(4):e58.

13. Read S, Malmström V, Powrie F: Cytotoxic T lymphocyte-associated antigen 4 plays an essential role in the function of $\mathrm{CD} 25(+) C D 4(+)$ regulatory cells that control intestinal inflammation. J Exp Med 2000 192(2):295-302

14. Liu Z, Geboes K, Hellings P, Maerten P, Heremans H, Vandenberghe P, Boon L, van Kooten $P$, Rutgeerts $P$, Ceuppens $J L$ : B7 interactions with CD28 and CTLA-4 control tolerance or induction of mucosal inflammation in chronic experimental colitis. J Immunol 2001 167(3):1830-1838

15. van Heel DA, Fisher SA, Kirby A, Daly MJ, Rioux JD, Lewis CM: Inflammatory bowel disease susceptibility loci defined by genome scan meta-analysis of 1952 affected relative pairs. Hum Mol Genet 2004, 13(7):763-770

16. Ueda H, Howson JM, Esposito L, Heward J, Snook H, Chamberlain G, Rainbow DB, Hunter KM, Smith AN, Di Genova G, et al:: Association of the T-cell regulatory gene CTLA4 with susceptibility to autoimmune disease. Nature 2003, 423(6939):506-511.

17. Howson JM, Walker NM, Smyth DJ, Todd JA: Analysis of 19 genes for association with type I diabetes in the Type I Diabetes Genetics Consortium families. Genes Immun 2009, 10(Suppl 1):S74-84

18. Xia B, Crusius JB, Wu J, Zwiers A, van Bodegraven AA, Pena AS: CTLA4 gene polymorphisms in Dutch and Chinese patients with inflammatory bowel disease. Scand J Gastroenterol 2002, 37(11):1296-1300

19. Machida $\mathrm{H}$, Tsukamoto $\mathrm{K}$, Wen $\mathrm{CY}$, Narumi $\mathrm{Y}$, Shikuwa $\mathrm{S}$, Isomoto $\mathrm{H}$, Takeshima F, Mizuta Y, Niikawa N, Murata I, et al:: Association of polymorphic alleles of CTLA4 with inflammatory bowel disease in the Japanese. World J Gastroenterol 2005, 11(27):4188-4193.

20. Rueda B, Zhernakova A, Lopez-Nevot MA, Gomez-Garcia M, Ortega E, Pinero A, Correro F, Brieva JA, Nieto A, Koeleman BP, et al:: CTLA4/CT60 polymorphism is not relevant in susceptibility to autoimmune inflammatory intestinal disorders. Hum Immuno/ 2005, 66(3):321-325.

21. Magyari L, Faragó B, Bene J, Horvatovich K, Lakner L, Varga M, Figler M, Gasztonyi B, Mózsik G, Melegh B: No association of the cytotoxic Tlymphocyte associated gene CTLA4 +49A/G polymorphisms with Crohn's disease and ulcerative colitis in Hungarian population samples. World J Gastroenterol 2007, 13(15):2205-2208.

22. IBD Working Group of the European Society for Paediatric Gastroenterology Hepatology and Nutrition.: Inflammatory bowe disease in children and adolescents: recommendations for diagnosis-the Porto criteria. J Pediatr Gastroenterol Nutr 2005, 41(1):1-7.

23. Silverberg MS, Satsangi J, Ahmad T, Arnott ID, Bernstein CN, Brant SR, Caprilli R, Colombel JF, Gasche C, Geboes K, et al:: Toward an integrated clinical, molecular and serological classification of inflammatory bowel disease: Report of a Working Party of the 2005 Montreal World Congress of Gastroenterology. Can J Gastroenterol 2005, 19(Suppl A):5-36

24. González JR, Armengol L, Solé X, Guinó E, Mercader JM, Estivill X, Moreno $\checkmark$ : SNPassoc: an R package to perform whole genome association studies. Bioinformatics 2007, 23(5):644-645.

25. Armuzzi A, Ahmad T, Ling KL, de Silva A, Cullen S, van Heel D, Orchard TR, Welsh KI, Marshall SE, Jewell DP: Genotype-phenotype analysis of the Crohn's disease susceptibility haplotype on chromosome 5q31. Gut 2003, 52(8):1133-1139.

26. Linderson Y, Bresso F, Buentke E, Pettersson S, D'Amato M: Functional interaction of CARD15/NOD2 and Crohn's disease-associated TNFalpha polymorphisms. Int J Colorectal Dis 2005, 20(4):305-311

27. Stoll M, Corneliussen B, Costello CM, Waetzig GH, Mellgard B, Koch WA, Rosenstiel P, Albrecht M, Croucher PJ, Seegert D, et al:: Genetic variation in DLG5 is associated with inflammatory bowel disease. Nat Genet 2004, 36(5):476-480.

28. Hampe J, Franke A, Rosenstiel P, Till A, Teuber M, Huse K, Albrecht M, Mayr G, De La Vega FM, Briggs J, et al:: A genome-wide association scan of nonsynonymous SNPs identifies a susceptibility variant for Crohn disease in ATG16L1. Nat Genet 2007, 39(2):207-211. 
29. Roberts RL, Gearry RB, Hollis-Moffatt JE, Miller AL, Reid J, Abkevich V Timms KM, Gutin A, Lanchbury JS, Merriman TR, et al.: IL23R R381Q and ATG16L1 T300A are strongly associated with Crohn's disease in a study of New Zealand Caucasians with inflammatory bowel disease. Am J Gastroenterol 2007, 102(12):2754-2761.

30. Browning BL, Annese V, Barclay ML, Bingham SA, Brand S, Büning C, Castro M, Cucchiara S, Dallapiccola B, Drummond H, et al:: Gender-stratified analysis of DLG5 R30Q in 4707 patients with Crohn disease and 4973 controls from 12 Caucasian cohorts. J Med Genet 2008, 45(1):36-42.

31. Cummings JR, Ahmad T, Geremia A, Beckly J, Cooney R, Hancock L, Pathan $\mathrm{S}$, Guo C, Cardon LR, Jewell DP: Contribution of the novel inflammatory bowel disease gene IL23R to disease susceptibility and phenotype. Inflamm Bowel Dis 2007, 13(9):1063-1068.

32. Török HP, Glas J, Endres I, Tonenchi L, Teshome MY, Wetzke M, Klein W Lohse P, Ochsenkühn T, Folwaczny M, et al:: Epistasis between Toll-like receptor-9 polymorphisms and variants in NOD2 and IL23R modulates susceptibility to Crohn's disease. Am J Gastroentero/ 2009, 104(7):1723-1733.

33. de Ridder L, Weersma RK, Dijkstra G, van der Steege G, Benninga MA, Nolte IM, Taminiau JA, Hommes DW, Stokkers PC: Genetic susceptibility has a more important role in pediatric-onset Crohn's disease than in adult-onset Crohn's disease. Inflamm Bowel Dis 2007، 13(9):1083-1092.

\section{Pre-publication history}

The pre-publication history for this paper can be accessed here: http://www.biomedcentral.com/1471-2350/11/91/prepub

doi: 10.1186/1471-2350-11-91

Cite this article as: Hradsky et al., The CTLA4 variants may interact with the IL23R- and NOD2-conferred risk in development of Crohn's disease BMC Medical Genetics 2010, 11:91

Submit your next manuscript to BioMed Centra and take full advantage of:

- Convenient online submission

- Thorough peer review

- No space constraints or color figure charges

- Immediate publication on acceptance

- Inclusion in PubMed, CAS, Scopus and Google Scholar

- Research which is freely available for redistribution

Submit your manuscript at www.biomedcentral.com/submit
C BioMed Central 